\title{
Development of bovine embryos in vitro following oocyte maturation under defined conditions
}

\author{
P Lonergan, C Carolan, P Mermillod * \\ INRA, Station de Physiologie de la Reproduction, 37380 Nouzilly, France
}

(Received 14 March 1994; accepted 4 May 1994)

\begin{abstract}
Summary - A total of 4615 immature bovine oocytes were used in a series of experiments aimed at the systematic evaluation of the role of the different components of our in vitro maturation (IVM) medium in imparting developmental competence to the oocytes. The results clearly demonstrate that both tissue culture medium 199 (M199) and synthetic oviduct fluid (SOF) are capable of supporting the IVM of bovine oocytes at high rates in the absence of macromolecular supplements, as evidenced by subsequent development to the blastocyst stage (20 and $25 \%$, respectively). However, both were significantly lower than the control (containing $10 \%$ fetal calf serum, $5 \mu \mathrm{g} / \mathrm{ml} \mathrm{pLH}$ (porcine luteinizing hormone), $1 \mu \mathrm{g} / \mathrm{ml} \mathrm{pFSH}$ (porcine follicle-stimulating hormone), and $1 \mu \mathrm{g} / \mathrm{ml}-17 \beta$-estradiol, E2) in terms of blastocyst yield. Inclusion of bovine serum albumin $(3 \mathrm{mg} / \mathrm{ml})$ was not beneficial and in fact significantly depressed development when added to SOF. It was shown that the advantage of the control conditions over unsupplemented M199 and SOF was entirely attributable to the presence of serum and that in the absence of serum the inclusion of the above hormone cocktail significantly depressed postcleavage development. When used individually, neither $\mathrm{LH}(50,500,5000 \mathrm{ng} / \mathrm{ml})$ nor $\mathrm{FSH}(10,100$, $1000 \mathrm{ng} / \mathrm{ml}$ ) improved development over M199 alone. In conclusion, we now have a simple maturation system, using a fully defined medium (M199) in which the search for factors improving the cytoplasmic competence acquisition of maturing cattle oocytes will be possible.
\end{abstract}

\section{IVM / IVF / oocyte / medium / bovine}

Résumé - Développement des embryons bovins in vitro suivant la maturation de l'ovocyte dans des conditions bien définies. Un total de 4615 ovocytes a été utilisé dans une série d'expériences destinées à évaluer l'effet respectif des différents composants du milieu de maturation in vitro (MIV) sur l'acquisition par les ovocytes bovins de leur compétence à se développer in vitro après fécondation (compétence cytoplasmique). Les résultats ont montré clairement que le milieu 199 (M199) et le fluide d'oviducte synthétique (SOF) sont capables à eux seuls de supporter la MIV d'ovocytes bovins. Cependant, les taux de développement jusqu'au stade de blastocyste observés après maturation dans ces milieux purs (20 et $25 \%$ respectivement) sont significativement inférieurs à ceux qui sont obtenus après maturation dans le milieu contrôle (M199 additionné de 10\% de sérum bovin fotal, $5 \mu \mathrm{g} / \mathrm{m} /$ de $\mathrm{pLH}, 1 \mu \mathrm{g} / \mathrm{m} /$ de $\mathrm{pFSH}$ et $1 \mu \mathrm{g} / \mathrm{m} /$ de $17 \beta$-œstradiol). L'ajout d'albumine bovine $(3 \mathrm{mg} / \mathrm{ml})$ à ces milieux

\footnotetext{
* Correspondence and reprints.
} 
n'améliore pas la qualité de la maturation. Au contraire, l'albumine diminue le taux de développement lorsqu'elle est ajoutée au SOF pendant la maturation. Nous avons montré que l'entièreté de l'effet bénéfique du milieu contrôle résidait dans la présence de sérum. En effet, les hormones (FSH et LH) ajoutées ensemble ou séparément (à différentes concentrations) au milieu de maturation n'améliorent pas la compétence cytoplasmique des ovocytes. En conclusion, nous disposons maintenant d'un système simple dans lequel nous allons pouvoir rechercher, parmi les constituants du sérum, ceux qui agissent sur la compétence cytoplasmique de l'ovocyte bovin.

MIV / FIV / ovocyte / milieu de culture / bovin

\section{INTRODUCTION}

In recent years substantial progress has been made in the development of procedures for the in vitro maturation (IVM), fertilization (IVF) and culture (IVC) of bovine embryos (for reviews, see Brackett and Zuelke, 1993; Trounson et al, 1994). However, further improvements are necessary to maximize embryo production. In most laboratories, the production of viable embryos plateaus out at $20-30 \%$ of inseminated oocytes in spite of numerous variations on the basic technique. It would appear that not all oocytes are fully capable of responding to the maturation conditions to which they are exposed. The shortfall in developmental ability is probably due to inadequacies in cytoplasmic maturation.

Much research in the area of in vitro cattle embryo production has been directed towards the identification of factors involved in imparting developmental competence to the oocyte following IVM. Factors important during IVM include: 1) the hormonal environment of the oocyte prior to and during IVM (Moor and Trounson, 1977; Zhang and Armstrong, 1989); 2) the presence of serum in the IVM medium (Downs et al, 1986); and 3 ) the association of follicular or cumulus cells (ie somatic factors) with the maturing oocyte (Vanderhyden and Armstrong, 1989). These factors may play a role in supporting oocyte cytoplasmic maturation, which is critical for subsequent fertilization and development.
It has been well established that culture conditions for IVM of mammalian oocytes can significantly influence the subsequent development of such oocytes (mouse: Eppig et al, 1990; Van de Sandt et al, 1990; pig: Yoshida et al, 1992; cattle: Fassi-Fihri et al, 1991; Keefer et al, 1991; Ectors et al, 1992; Rose and Bavister, 1992). However, the specific mechanisms by which various IVM medium components affect subsequent development remain speculative. The situation is further confused by the chemical heterogeneity introduced into the medium by serum.

The present series of experiments involved the use of 4615 immature bovine oocytes to systematically examine the role of the components of our IVM medium to determine their relative importance in imparting developmental competence to the oocytes.

\section{MATERIALS AND METHODS}

\section{General procedures}

\section{Oocyte collection and maturation}

Oocytes were obtained by aspiration of 2- $6 \mathrm{~mm}$ follicles of ovaries from slaughtered cows. All oocytes completely surrounded by unexpanded cumulus cells were used (average 5.7 oocytes per ovary); they were washed 4 times in modified phosphate-buffered saline (PBS) (supplemented with pyruvate $36 \mathrm{mg} / \mathrm{l}$, gentamycin and $0.5 \mathrm{mg} / \mathrm{ml}$ bovine serum albumin, BSA Sigma 
fraction V, cat \# A9647). Groups of up to 50 oocytes were transferred to 4-well plates (Nunc, Roskilde, Denmark) containing $500 \mu$ l of medium for $24 \mathrm{~h}$ maturation at $39^{\circ} \mathrm{C}$ in an atmosphere of $5 \% \mathrm{CO}_{2}$ in air with maximum humidity.

The control medium used for maturation throughout all experiments consisted of tissue culture medium 199 (M199, Gibco, Paisley, Scotland, cat \#041-01150H) supplemented with 10\% heat-treated fetal calf serum (FCS, Gibco cat $\# 011-06180 \mathrm{H}$ ), $5 \mu \mathrm{g}$ porcine luteinizing hormone (pLH) per $\mathrm{ml}, 1 \mu \mathrm{g}$ porcine follicle-stimulating hormone (pFSH) per ml and $1 \mu \mathrm{g} 17 \beta$-estradiol (E2) $\mathrm{ml}$. pLH and $\mathrm{pFSH}$ were supplied by JF Beckers, Liège, Belgium).

\section{In vitro fertilization}

Following maturation, cumulus expansion was visually assessed under a stereo-microscope. Oocytes were then washed 4 times in PBS and once in fertilization medium before being transferred in groups of up to 100 into 4-well plates containing $250 \mu \mathrm{l}$ fertilization medium (TALP, containing $10 \mu \mathrm{g}$ heparin-sodium salt $(167 \mathrm{U} / \mathrm{mg}$, Calbiochem, San Diego, CA) per ml) per well. Motile spermatozoa were obtained by centrifugation of frozen-thawed spermatozoa on a Percoll (Pharmacia, Uppsala, Sweden) discontinuous density gradient ( $2 \mathrm{ml}$ at $45 \%$ over $2 \mathrm{ml}$ at $90 \%$ ) for 20-30 min at $700 \mathrm{~g}$ at room temperature. The same ejaculate from one bull was used throughout all experiments. Viable spermatozoa, collected at the bottom of the $90 \%$ fraction were washed in TALP and pelleted by centrifugation at $100 \mathrm{~g}$ for $10 \mathrm{~min}$ at room temperature. Spermatozoa were counted in a hemocytometer and diluted in the appropriate volume of TALP to give a concentration of $4 \times 10^{6}$ spermatozoa/ml; $250 \mu$ l of this suspension was added to each fertilization well to obtain a final concentration of $2 \times 10^{6}$ spermatozoa $/ \mathrm{ml}$. Plates were then incubated for $18-21 \mathrm{~h}$ in $5 \% \mathrm{CO}_{2}$ in humidified air at $39^{\circ} \mathrm{C}$.

\section{In vitro culture}

For all experiments culture took place in modified synthetic oviduct fluid medium (SOF; Takahashi and First, 1992) under paraffin oil in a humidified atmosphere of $5 \% \mathrm{CO}_{2}, 5 \% \mathrm{O}_{2}, 90 \%$ $\mathrm{N}_{2}$ at $39^{\circ} \mathrm{C}$. Cumulus cells were removed from presumptive zygotes by vortexing for $2 \mathrm{~min}$ in $2 \mathrm{ml}$ PBS. The zygotes were subsequently washed twice in PBS and twice in SOF before being transferred to the culture droplets ( 1 zygote/ $\mu$ l medium). Fetal calf serum was added $(10 \% \mathrm{v} / \mathrm{v}) 24 \mathrm{~h}$ after placement in culture (ie $48 \mathrm{~h}$ post-fertilization). Cleavage was assessed $48 \mathrm{~h}$ after placement in culture ( $\%$ non-cleaved, $2-4$ cells, $5-8$ cells). The number of embryos developing to the expanded blastocyst stage was assessed on days $6-8$ of culture. Hatching was recorded on day 8 of culture. It should be noted that while this hatching rate was sufficient for comparisons among treatments it should not be considered as representative of the total hatching rate in our system as in cases where culture was continued beyond day 8 additional hatching occurred.

While every effort was made to totally remove cumulus cells prior to placement in culture, this was not achieved in all cases, with a monolayer being evident in the culture droplet at the end of the culture period. Preliminary experiments would suggest that these cells are not essential for embryo development.

\section{Experiment 1: effect of basal medium used during IVM on subsequent development}

In an effort to see if the SOF we used for culture of post-fertilization embryos could support IVM without adversely affecting subsequent development, oocytes were matured in either M199, SOF (as used for embryo culture, ie with $3 \mathrm{mg} / \mathrm{ml}$ BSA but without serum) or control medium (see above) (Experiment 1a).

To ensure that the effect of the SOF above was not due solely to the presence of BSA, a second experiment was performed in which BSA was added to M199 at the same concentration $(3 \mathrm{mg} / \mathrm{ml}$ ) during maturation (Experiment $1 \mathrm{~b}$ ).

\section{Experiment 2: effect of addition of hormones and/or serum to the IVM medium on subsequent development}

(a) $\mathrm{M} 199$ vs $\mathrm{M} 199+\mathrm{H}$ vs $\mathrm{M} 199+\mathrm{FCS}$ vs Control

(b) SOF vs SOF $+\mathrm{H} v s \mathrm{SOF}+\mathrm{FCS} v s \mathrm{SOF}+\mathrm{H}$ + FCS vs Control

Oocytes were matured in either M199 or SOF. This was used supplemented with (i) $\mathrm{H}: 5 \mu \mathrm{g}$ 
$\mathrm{LH} / \mathrm{ml}, 1.0 \mu \mathrm{g} \mathrm{pFSH} / \mathrm{ml}, 1 \mu \mathrm{g} 17 \beta$-estradiol; (ii) $10 \%$ heat-treated FCS; or (iii) a combination of (i) and (ii).

\section{Experiment 3: effect of addition of pFSH to IVM medium on subsequent development}

To assess the effect of FSH on development, oocytes were matured in $\mathrm{M} 199$ alone or in the presence of pFSH at 10,100 or $1000 \mathrm{ng} / \mathrm{ml}$.

\section{Experiment 4: effect of $p L H$ addition to IVM medium on subsequent development}

To assess the effect of LH on development, oocytes were matured in M199 alone or in the presence of $\mathrm{pLH}$ at 50,500 , or $5000 \mathrm{ng} / \mathrm{ml}$.

\section{RESULTS}

\section{Experiment 1a}

The results are shown in table I. In the majority of cases with M199 and in all cases with SOF, oocytes did not exhibit cumulus expansion following IVM. Oocytes matured in control medium always exhibited pronounced expansion. There was no signifi- cant difference in terms of cleavage rate, $\%$ 5-8 cells or hatching rate between any of the 3 groups. While there was no significant differences between M199 and SOF in terms of blastocyst yield, both were significantly lower than the control $(P<0.05)$ expressed as a percentage of oocytes inseminated (20 and 25 vs $37 \%$, respectively) or oocytes cleaved (24 and 31 vs $44 \%$, respectively).

\section{Experiment $1 b$}

The results are shown in table II. Addition of BSA to M199 had no effect on any of the parameters studied. In contrast, addition of BSA to SOF significantly reduced the blastocyst yield, taken either as a percentage of oocytes inseminated (31 vs 17\%, respectively) or oocytes cleaved (40 vs $25 \%$, respectively). Both $\mathrm{M} 199$ and SOF, either in the presence or absence of BSA were significantly lower than the control in terms of blastocyst yield.

\section{Experiment 2}

The results are shown in tables III and IV. Addition of hormones and serum, either alone or in combination with M199 and SOF had a marked positive effect on cumulus

Table I. Effect of medium used during IVM on subsequent bovine embryo development.

\begin{tabular}{lcccccc} 
Treatment & Ova * & $\begin{array}{c}\text { No embryos } \\
\text { cleaved (\%) }\end{array}$ & $\begin{array}{r}\text { No embryos } \\
5-8 \text { cell (\%) }\end{array}$ & $\begin{array}{r}\text { No embryos } \\
\text { blastocysts on } \\
\text { day } 8(\%)\end{array}$ & $\begin{array}{c}\% \text { blastocysts } \\
\text { /cleaved }\end{array}$ & $\begin{array}{r}\text { No embryos } \\
\text { hatched on } \\
\text { day } 8 \text { (\% hatching) }\end{array}$ \\
\hline M199 & 168 & $136(81)$ & $84(50)$ & $33^{\mathrm{a}}(20)$ & $24^{\mathrm{a}}$ & $13(39)$ \\
SOF + BSA & 185 & $146(79)$ & $90(49)$ & $46^{\mathrm{a}}(25)$ & $31^{\mathrm{a}}$ & $20(43)$ \\
Control & 191 & $159(83)$ & $105(55)$ & $70^{\mathrm{b}}(37)$ & $44^{\mathrm{b}}$ & $31(44)$
\end{tabular}

a,b.c Values in the same column with different superscripts differ significantly $\left(\chi^{2}, P<0.05\right)$. * Total of 3 replicates. Control: M199 supplemented with $5 \mu \mathrm{g} / \mathrm{ml} \mathrm{LH}+1 \mu \mathrm{g} / \mathrm{ml} \mathrm{FSH}+1 \mu \mathrm{g} / \mathrm{ml} \mathrm{E} \mathrm{E}_{2}+10 \%$ FCS. 
Table II. Effect of BSA inclusion in IVM medium on subsequent bovine embryo development.

\begin{tabular}{|c|c|c|c|c|c|c|}
\hline Treatment & $B S A$ & Ova * & $\begin{array}{l}\text { No embryos } \\
\text { cleaved (\%) }\end{array}$ & $\begin{array}{l}\text { No embryos } \\
5-8 \text { cell (\%) }\end{array}$ & $\begin{array}{l}\text { No embryos } \\
\text { blastocysts } \\
\text { on day } 8(\%)\end{array}$ & $\begin{array}{l}\text { \% blastocysts } \\
\text { /cleaved }\end{array}$ \\
\hline \multirow[t]{2}{*}{ M199 } & - & 119 & $78^{a}$ & $51(43)$ & $24^{a b}(20)$ & $31^{a b}$ \\
\hline & + & 131 & $96 \mathrm{ab}(73)$ & $61(47)$ & $31^{a b}(24)$ & $32^{\mathrm{ab}}$ \\
\hline \multirow[t]{2}{*}{ SOF } & - & 106 & $83^{b} \quad(78)$ & $48(45)$ & $33^{\mathrm{ac}}(31)$ & $40^{\mathrm{ac}}$ \\
\hline & + & 124 & $83^{a b}(67)$ & $50(40)$ & $21^{\mathrm{b}}$ & $25^{b}$ \\
\hline Control & & 118 & $85^{\mathrm{ab}}(72)$ & $51(43)$ & $44^{c} \quad(37)$ & $52^{\circ}$ \\
\hline
\end{tabular}

$a, b, c$ Values in the same column with different superscripts differ significantly $\left(\chi^{2}, P<0.05\right)$. * Total of replicates. Control: M199 supplemented with $5 \mu \mathrm{g} / \mathrm{ml} \mathrm{LH}+1 \mu \mathrm{g} / \mathrm{ml} \mathrm{FSH}+1 \mu \mathrm{g} / \mathrm{ml} \mathrm{E}_{2}+10 \% \mathrm{FCS}$.

Table III. Effect of addition of serum and/or hormones to M199 during IVM on subsequent bovine embryo development.

\begin{tabular}{lccccc}
\hline Treatment & Ova * & $\begin{array}{c}\text { No embryos } \\
\text { cleaved (\%) }\end{array}$ & $\begin{array}{c}\text { No embryos } \\
5-8 \text { cell (\%) }\end{array}$ & $\begin{array}{c}\text { No embryos } \\
\text { blastocysts } \\
\text { on day } 8(\%)\end{array}$ & $\begin{array}{c}\% \text { blastocysts } \\
\text { /cleaved }\end{array}$ \\
\hline M199 & 159 & $130^{\mathrm{a}}(82)$ & $82(52)$ & $44^{\mathrm{a}}(28)$ & $34^{\mathrm{ab}}$ \\
M199+H & 157 & $118^{\mathrm{ac}}(75)$ & $80(51)$ & $27^{\mathrm{b}}(17)$ & $23^{\mathrm{b}}$ \\
M199+S & 171 & $118^{\mathrm{bc}}(69)$ & $89(52)$ & $53^{\mathrm{a}}(31)$ & $45^{\mathrm{a}}$ \\
Control & 213 & $163^{\mathrm{ac}}(76)$ & $119(56)$ & $60^{\mathrm{a}}(28)$ & $37^{\mathrm{a}}$ \\
\hline
\end{tabular}

a,b,c Values in the same column with different superscripts differ significantly $\left(\chi^{2}, \mathrm{P}<0.05\right)$. *Total of 4 replicates. Control: M199 supplemented with $5 \mu \mathrm{g} / \mathrm{ml} \mathrm{LH}+1 \mu \mathrm{g} / \mathrm{ml} \mathrm{FSH}+1 \mu \mathrm{g} / \mathrm{ml} \mathrm{E}_{2}+10 \%$ FCS.

expansion. Addition of hormones to M199 significantly depressed the yield of blastocysts after IVF compared with M199 alone. This effect of hormones was removed in the presence of serum. There was no difference, however, between IVM in M199 alone, $\mathrm{M} 199$ + serum, or the control.

Addition of hormones to SOF during IVM significantly depressed the subsequent blastocyst hatching rate. As observed with M199, the addition of serum completely blocked this effect.

\section{Experiment 3}

The results are shown in table $\mathrm{V}$. FSH at any of the concentrations studied significantly improved cumulus expansion compared with M199 alone. Addition of 100 $\mathrm{ng} / \mathrm{ml} \mathrm{FSH}$ significantly increased the cleavage rate over that of $\mathrm{M} 199$ alone. However, at higher $(1000 \mathrm{ng} / \mathrm{ml})$ or lower $(10 \mathrm{ng} / \mathrm{ml})$ concentrations there was no difference. Addition of FSH at any of the concentrations studied had no effect on blastocyst 
Table IV. Effect of addition of serum and/or hormones to SOF during IVM on subsequent bovine embryo development.

\begin{tabular}{|c|c|c|c|c|c|}
\hline Treatment & Ova * & $\begin{array}{l}\text { No embryos } \\
\text { cleaved (\%) }\end{array}$ & $\begin{array}{l}\text { No embryos } \\
5-8 \text { cell (\%) }\end{array}$ & $\begin{array}{c}\text { No embryos } \\
\text { blastocysts } \\
\text { on day } 8(\%)\end{array}$ & $\begin{array}{c}\% \text { blastocysts } \\
\text { /cleaved embryos } \\
\text { hatched on } \\
\text { day } 8 \text { (\% hatching) }\end{array}$ \\
\hline
\end{tabular}

\begin{tabular}{llllllll}
\hline SOF & 180 & $144(80)$ & $105^{\mathrm{a}}(58)$ & $34^{\mathrm{a}}(19)$ & $24^{\mathrm{a}}$ & $14^{\mathrm{ac}}(41)$ \\
SOF + H & 160 & $130(81)$ & $8^{\mathrm{ab}}(53)$ & $35^{\mathrm{a}}(22)$ & $27^{\mathrm{ac}}$ & $8^{\mathrm{a}}(23)$ \\
SOF + FCS & 166 & $130(78)$ & $8^{\mathrm{ab}}(49)$ & $30^{\mathrm{a}}(18)$ & $23^{\mathrm{a}}$ & $15^{\mathrm{bc}}(50)$ \\
SOF + H + FCS & 162 & $118(73)$ & $7^{\mathrm{b}}(46)$ & $43^{\mathrm{ab}}(27)$ & $36^{\mathrm{bcd}}$ & $22^{\mathrm{bc}}(51)$ \\
Control & 163 & $126(77)$ & $9^{\mathrm{ab}}(56)$ & $54^{\mathrm{b}}(33)$ & $43^{\mathrm{d}}$ & $26^{\mathrm{bc}}(48)$ \\
\hline
\end{tabular}

a,b,c Values in the same column with different superscripts differ significantly $\left(\chi^{2}, P<0.05\right) .{ }^{*}$ Total of 4 replicates. Control: M199 supplemented with $5 \mu \mathrm{g} / \mathrm{ml} \mathrm{LH}+1 \mu \mathrm{g} / \mathrm{ml} \mathrm{FSH}+1 \mu \mathrm{g} / \mathrm{ml} \mathrm{E}_{2}+10 \% \mathrm{FCS}$.

Table V. Effect of pFSH addition to IVM medium on subsequent bovine embryo development.

\begin{tabular}{lcccccc}
\hline Treatment & Ova * & $\begin{array}{c}\text { No embryos } \\
\text { cleaved (\%) }\end{array}$ & $\begin{array}{c}\text { No embryos } \\
5-8 \text { cell (\%) }\end{array}$ & $\begin{array}{c}\text { No embryos } \\
\text { blastocysts } \\
\text { on day } 8(\%)\end{array}$ & $\begin{array}{c}\% \text { blastocysts } \\
\text { /cleaved }\end{array}$ & $\begin{array}{c}\text { No embryos } \\
\text { hatched on } \\
\text { day } 8 \text { (\% hatching) }\end{array}$ \\
\hline M199 & 174 & $140^{\mathrm{a}}(80)$ & $87(50)$ & $34^{\mathrm{a}}(19)$ & $24^{\mathrm{a}}$ & $15(44)$ \\
$10 \mathrm{ng}$ & 174 & $151^{\mathrm{ab}}(87)$ & $100(57)$ & $31^{\mathrm{a}}(18)$ & $20^{\mathrm{a}}$ & $10^{\mathrm{a}}(32)$ \\
$100 \mathrm{ng}$ & 172 & $153^{\mathrm{b}}(89)$ & $98(57)$ & $43(25)$ & $28^{\mathrm{ab}}$ & $12^{\mathrm{a}}(28)$ \\
$1000 \mathrm{ng}$ & 162 & $135^{\mathrm{ab}}(83)$ & $80(49)$ & $31^{\mathrm{a}}(19)$ & $23^{\mathrm{a}}$ & $16^{\mathrm{b}}(52)$ \\
Control & 176 & $146^{\mathrm{ab}}(83)$ & $91(52)$ & $55^{\mathrm{b}}(31)$ & $38^{\mathrm{b}}$ & $30^{\mathrm{b}}(54)$ \\
\hline
\end{tabular}

a,b,c Values in the same column with different superscripts differ significantly $\left(\chi^{2}, P<0.05\right)$. $T$ Total of 3 replicates. Control: M199 supplemented with $5 \mu \mathrm{g} / \mathrm{ml} \mathrm{LH}+1 \mu \mathrm{g} / \mathrm{ml} \mathrm{FSH}+1 \mu \mathrm{g} / \mathrm{ml} \mathrm{E}_{2}+10 \% \mathrm{FCS}$.

yield compared to M199 alone. All concentrations except $100 \mathrm{ng}$ FSH were significantly lower than the control in terms of blastocyst yield.

\section{Experiment 4}

The results are shown in table VI. Addition of $\mathrm{LH}$ at concentrations in excess of 50 $\mathrm{ng} / \mathrm{ml}$ significantly improved cumulus expan- sion compared to M199 alone. There was no significant difference in terms of cleavage rate amongst any of the 5 treatment groups. There was not much variation in the $\% 5-8$ cell embryos at $72 \mathrm{hpi}$, except between 50 $\mathrm{ng} \mathrm{LH}$ and $5000 \mathrm{ng} \mathrm{LH}(P<0.05,39$ vs $51 \%$, respectively). In terms of blastocyst yield, expressed either as a percentage of oocytes inseminated or of oocytes cleaved, there was no difference between maturation in M199 alone or in the presence of $\mathrm{LH}$ at any of the concentrations studied. How- 
Table VI. Effect of pLH addition during IVM on subsequent bovine embryo development.

\begin{tabular}{lcccccc}
\hline Treatment & $N$ & Ova & $\begin{array}{c}\text { No embryos } \\
\text { cleaved (\%) }\end{array}$ & $\begin{array}{c}\text { No embryos } \\
5-8 \text { cell }(\%)\end{array}$ & $\begin{array}{c}\text { No embryos } \\
\text { blastocysts on } \\
\text { day } 8(\%)\end{array}$ & $\begin{array}{c}\% \text { blastocysts } \\
\text { /cleaved }\end{array}$ \\
\hline M199 & 4 & 167 & $167(72)$ & $79^{\mathrm{ab}}(47)$ & $40^{\mathrm{a}}(24)$ & $33^{\mathrm{a}}$ \\
$50 \mathrm{ng}$ & 3 & 155 & $109(70)$ & $60^{\mathrm{a}}(39)$ & $33^{\mathrm{a}}(21)$ & $30^{\mathrm{a}}$ \\
$500 \mathrm{ng}$ & 5 & 263 & $194(74)$ & $121^{\mathrm{ab}}(46)$ & $56^{\mathrm{a}}(21)$ & $29^{\mathrm{a}}$ \\
5 O00 ng & 5 & 280 & $218(78)$ & $143^{\mathrm{b}}(51)$ & $75^{\mathrm{a}}(27)$ & $34^{\mathrm{a}}$ \\
Control & 5 & 219 & $172(78)$ & $101^{\mathrm{ab}}(46)$ & $87^{\mathrm{b}}(40)$ & $51^{\mathrm{b}}$ \\
\hline
\end{tabular}

a,b Values in the same column with different superscripts differ significantly $\left(\chi^{2}, P<0.05\right)$. N: number of replicates. Control: M199 supplemented with $5 \mu \mathrm{g} / \mathrm{ml} \mathrm{LH}+1 \mu \mathrm{g} / \mathrm{ml} \mathrm{FSH}+1 \mu \mathrm{g} / \mathrm{ml} \mathrm{E} 2+10 \% \mathrm{FCS}$.

ever, all were significantly lower than the control for both parameters.

\section{DISCUSSION}

Two principal factors known to influence the IVM process in many species are protein and hormonal media supplements. The complex culture medium TCM 199 buffered with bicarbonate or HEPES and supplemented with various sera and/or gonadotropin (FSH, LH) and/or steroid $\left(E_{2}\right)$ hormones has been the most widely used culture medium for the study of bovine oocyte maturation. It has also been reported that follicular somatic cells affect subsequent in vitro development when oocytes are cultured with these cells during IVM (Staigmiller and Moor, 1984; Critser et al, 1986; Lu and Gordon, 1987; Lutterbach et al, 1987; Faundez et al, 1988; Chikamatsu et al, 1989). However, as pointed out by Downs et al (1991), the presence of unidentified components or contaminants in these supplements makes it difficult to know with certainty whether the response of the oocyte is attributable to a certain hormonal or chemical manipulation during culture or is, at least in part, influenced by unknown components of the supplement.

The results of Experiment 1 demonstrate that both M199 and SOF are capable of supporting the IVM of bovine oocytes in the absence of macromolecular supplements as evidenced by subsequent development, although to a lower extent than control conditions in terms of blastocyst yield. It was also clearly demonstrated that BSA is not a necessary supplement and in fact depresses blastocysts yield when added to SOF.

It has been shown that cumulus expansion is not necessary to achieve normal nuclear configurations during IVM (Sirard et al, 1988). The present study confirms this finding by taking the results further along the developmental axis, ie to the blastocyst stage. In the majority of experiments using M199 alone for IVM, and in all those using SOF alone for IVM, no cumulus expansion was observed; however, subsequent blastocyst yields were unaffected. In some instances, oocytes exhibited pronounced expansion in M199 alone. The reasons for the inconsistency are unclear but are probably partly related to the number of oocytes cultured per unit volume as well as the 
amount of cumulus cover per oocyte. Olson et al (1991) found that while supplementation of the IVM medium with FSH (50 $\mathrm{ng}$ ) and/or LH $(1 \mu \mathrm{g})$ markedly enhanced cumulus expansion, it did not affect cleavage rate or early development. This is in agreement with the results of the present study where expansion was observed after inclusion of $\mathrm{pFSH}$ at any concentration studied and at $\mathrm{pLH}$ concentrations above $50 \mathrm{ng} / \mathrm{ml}$.

There are conflicting reports in the literature regarding the necessity for and optimal concentrations of hormones and serum. The addition of gonadotropins, $\mathrm{LH}$ and/or FSH during IVM has been shown to improve the developmental potential for oocytes of the mouse (Jinno et al, 1989; Downs et al, 1991), rat (Shalgi et al, 1979; Vanderhyden and Armstrong, 1990), rabbit (Yoshimura et al, 1989), goat (Younis et al, 1991), sheep (Moor and Trounson, 1977; Staigmiller and Moor, 1984), and cow (Fukushima and Fukui, 1985; Brackett et al, 1989; Younis et al, 1989; Zuelke and Brackett, 1990). However, other authors have reported no effect of exogenous hormones (Fukui and Ono, 1989; Keefer et al, 1993). While the reasons for such discrepancies are not always clear they are probably partly related to differences in the presence/absence of serum and also due to differences in post-fertilization culture systems. The ability of proteinfree defined culture medium to support hormonally enhanced bovine IVM has been demonstrated (Larson and Parks, 1990; Zuelke and Brackett, 1990; Coskun et al, 1991; Saeki et al, 1991; Ectors et al, 1992).

In the present study, the addition of both FSH and LH together to M199 or SOF depressed the blastocyst yield and hatching rate, following IVF. This effect was removed in the presence of serum. This is consistent with the known protective effect of serum and underlines the need to use a serum-free medium when testing the effects of exogenous substances. As pointed out by Downs et al (1991), the choice of macro- molecular supplement is critical when testing the hormone responsiveness of isolated cumulus enclosed oocytes in culture. Most serum contains factors that suppress the hormone-induced response, emphasizing the importance of choosing medium supplements carefully.

When used individually, neither LH nor $\mathrm{FSH}$, at any of the concentrations used, improved development over that of M199 alone. This suggests that in cases where the control was superior to M199 the beneficial effect was fully attributable to the presence of serum. It should be noted that in some experiments (see tables II and III) no beneficial effect of serum was observed. The reasons for the discrepancy are unclear but may be due to differences in responsiveness among oocyte batches. The reason for the failure to show a positive effect of hormones in the present study compared to other reports lies in part in the fact that in our system the use of unsupplemented M199 results in higher yields of embryos following IVF than reported by most authors, rather than a reduced effect of the added hormones. The reasons for this may include differences in media use (we have observed marked differences in batches of M199), the quality of the water used in media preparation, differences among batches of oocytes (perhaps relating to variations in time and conditions from ovary collection to oocyte submission to IVM) and conditions of post-fertilization culture.

It is perhaps worth pointing out that $E_{2}$ was not tested individually for 2 reasons. Firstly, due to its volatile nature it is likely that by the end of culture the amount of $E_{2}$ is negligible. Secondly, it has been shown (Bindal et al, 1988) that lipophilic impurities in commercial preparations of phenol red, a $\mathrm{pH}$ indicator dye commonly used in tissue culture media (eg, TCM 199) have weak estrogenic activity. As a result, the validity of assessing the effect of $E_{2}$ in such media is questionable. 
It is interesting to note that rates of fertilization as assessed by cleavage after insemination were apparently unaffected by the presence of serum. This would suggest that zona hardening is not a problem in bovine oocytes as has been reported in mice (Downs et al, 1986) and rats (Vanderhyden et al, 1989; Zhang et al, 1991).

Despite a wide variety of protocols for the production of bovine embros, no one system has been proven to be consistently better. While a certain proportion of early developmental failure may be attributable to suboptimal culture conditions, it is clear from the work of many authors that germinal vesicle stage oocytes may not be developmentally equivalent. Indeed, one could question whether blastocyst yields in excess of $50 \%$ are realistically consistently achievable in practice given the morphological/qualitative heterogeneity of the raw material we began with (ie oocytes from slaughterhouse ovaries). As noted by Kruip et al (1979) no single culture system is likely to provide ideal conditions for oocytes obtained from every class of follicle. While oocytes for IVM are usually obtained from follicles 2-6 mm in size and at least 4-10 days away from any possible ovulation (Sirard et al, 1992), oocytes resuming meiosis in vivo originate from dominant follicles of about $15 \mathrm{~mm}$ in size (Pavlok et al, 1992). In addition, the IVM period lasts only $24 \mathrm{~h}$, while the dominant follicle grows from 4 to $15 \mathrm{~mm}$ for approximately $5 \mathrm{~d}$. It is likely therefore that developmental heterogeneity of chromosomally mature oocytes reflects intrinsic influences on the oocyte that occur differentially among follicles. Despite endless modifications of the IVM medium therefore, there may be a biological limit on the blastocyst yields achievable. It may well be that a prematuration treatment is necessary in order to allow the oocytes from smaller follicles, ie with 'interrupted' of folliculogenesis, to 'catch up' with those from larger follicles or those matured totally in vivo.
In conclusion to the present study, the identification of M199 as a completely defined medium capable of supporting the IVM of bovine oocytes in the absence of serum is an important step forward in the development of tools for the study of the specific metabolic requirements of maturing bovine oocytes. Studies in our laboratory are continuing to evaluate which serum components are responsible for the improved developmental competence of oocytes following IVM.

\section{ACKNOWLEDGMENTS}

The authors express their gratitude to $V$ Garnier for help in media prepartion and to the staff at the Blois and Tours Abattoirs for allowing access to ovaries. Thanks also to $D$ Bouttier of $\mathrm{ClA}$ URCO, La Futoue, Rouillon, France for providing bull semen and to JF Beckers for providing pure $\mathrm{pLH}$ and $\mathrm{pFSH}$. This work was financially supported by EEC (DG XII, grant BIO2-CT920067) and INRA (AIP Ovocyte) grants.

\section{REFERENCES}

Bindal RD, Carlson KE, Katzenellenbogen BS, Katzenellenbogen JA (1988) Lipophilic-impurities, not phenolsulfonphthalein, account for the estrogenic activity in commercial preparations of phenol red. $J$ Steroid Biochem 31, 287-293

Brackett BG, Zuelke KA (1993) Analysis of factors involved in the in vitro production of bovine embryos. Theriogenology 39, 43-64

Brackett BG, Younis Al, Fayrer-Hosken RA (1989) Enhanced viability after in vitro fertilization of bovine oocytes matured in vitro with high concentrations of Iuteinizing hormone. Fertil Steril 52, 319-324

Chikamatsu N, Urakawa M, Fukui Y, Aoyagi Y, Ono H (1989) In vitro fertilization and early development of bovine follicular oocytes matured in different culture systems and inseminated with spermatozoa treated by different methods. Jpn J Anim Reprod 35, 154-158

Coskun S, Sanbuissho A, Lin YC, Rikihisa Y (1991) Fertilizability and subsequent developmental ability of bovine oocytes matured in medium containing epidermal growth factor (EGF). Theriogenology 36,485 494 
Critser ES, Leibfried-Rutledge ML, First NL (1986) Influence of cumulus cell association during in vitro maturation of bovine oocytes on embryonic development. Biol Reprod 34 (Suppl 1), 286

Downs SM, Schroeder AC, Eppig JJ (1986) Serum maintains the fertilizability of mouse oocytes matured in vitro by preventing hardening of the zona pellucida. Gamete Res 15, 115-122

Downs SM, Dow MPD, Fagbohun CF (1991) The meiotic response of cumulus cell-enclosed mouse oocytes to follicle-stimulating hormone in the presence of different macromolecules. J Exp Zool258, 373-383

Ectors FJ, Fontes RS, Thonon F et al (1992) Effect of non-protein medium during in vitro maturation on in vitro development of bovine embryos. Theriogenology 37, 206

Eppig JJ, Schroeder AC, Van de Sandt JJM, Ziomek CA, Bavister BD (1990) Developmental capacity of mouse oocytes that grow and mature in culture: the effect of modification of the protocol. Theriogenology $33,89-100$

Fassi-Fihri N, Chupin D, Marquant-Le Guienne B, Thibier $M$ (1991) Critical effect of granulosa cells from preovulatory follicles on IVM, IVF and embryonic development in cattle. Theriogenology 35,128

Faundez R, Spohr l, Boryczko Z (1988) Effect of follicle cells on maturation and in vitro fertilization of cattle oocytes. Proc 11 th Int Congr Anim Reprod and Al (Dublin), 3, 325

Fukui $Y$, Ono $H$ (1989) Effects of sera, hormones and granulosa celts added to culture medium for in vitro maturation, fertilization, cleavage and development of bovine oocytes. J Reprod Fertil 86, 501-506

Fukushima M, Fukui $Y$ (1985) Effect of gonadotropins and steroids on the subsequent fertilizability of extrafollicular bovine oocytes cultured in vitro. Anim Reprod Sci 9, 323-332

Jinno M, Sandow BA, Hodgen GC (1989) Enhancement of the developmental potential of mouse oocytes matured in vitro by gonadotropins and ethyendiaminetetraacetic acid (EDTA). Jin Vitro Fertil Embryo Transfer $6,36-40$

Keefer CL, Strice SL, Maki-Laurila M (1991) Bovine embryo development in vitro: effect of in vitro maturation conditions on fertilization and blastocyst development. Theriogenology 35, 223

Keefer CL, Stice SL, Dobrinsky J (1993) Effect of folliclestimulating hormone and luteinizing hormone during bovine in vitro maturation on development following in vitro fertilization and nuclear transfer. Mol Reprod Dev 36, 469-474

Kruip TAM, Dieleman SJ, Moor RM (1979) Steroid production by bovine follicles in vitro: influence of size, stage of cycle and culture system. Ann Biol Anim Biochim Biophys 19, 1537-1545

Larson SF, Parks JE (1990) In vitro maturation and fertilization of bovine oocytes in defined medium. Biol Reprod 42 (Suppl 1), 92
Lu KH, Gordon I (1987) Effect of serum, hormones and cumulus cells of the in vitro maturation of bovine oocytes. Proc Soc Study of Fertil (York), Abstr 81

Lutterbach A, Koll RA, Brem G (1987) In vitro maturation of bovine oocytes in coculture with granulosa cells and their subsequent fertilization and development. Zuchthygiene 22, 145-150

Moor RM, Trounson AO (1977) Hormonal and follicular factors affecting maturation of sheep oocytes in vitro and their subsequent developmental capacity. $J$ Reprod Fertil 49, 101-109

Olson SE, Thomas WK, Seidel GE (1991) Effects of gonadotropins during in vitro maturation of bovine oocytes on subsequent embryonic development. Theriogenology 35, 250

Pavlok A, Lucas-Hahn A, Niemann H (1992) Fertilization and developmental competence of bovine ooytes derived from different categories of antral follicles. MOl Reprod Dev 31, 63-67

Rose TA, Bavister BD (1992) Effect of oocyte maturation medium on in vitro development of in vitro fertilized bovine embryos. Mol Reprod Dev 31, 72-77

Saeki K, Hoshi M, Leibfried-Rutledge ML, First NL (1991) In vitro fertilization and development of bovine oocytes matured in serum-free medium. Biol Reprod $44,256-260$

Shalgi R, Dekel N, Kraicer PF (1979) The effect of LH on the fertilizability and developmental capacity of rat oocytes matured in vitro. J Reprod Fertil 55, 429435

Sirard MA, Parrish JJ, Ware CB, Leibfried-Rutledge ML, First NL (1988) Culture of bovine oocytes to obtain developmentally competent embryos. Biol Reprod $39,546-552$

Sirard MA, Coenen K, Bilodeau S (1992) Effects of fresh or cultured follicular fractions on meiotic resumption in bovine oocytes. Theriogenology 37, 39-57

Staigmiller RB, Moor RM (1984) Effect of follicle cells on the maturation and developmental competence of ovine oocytes matured outside the follicle. Gamete Res $9,221-229$

Takahashi Y, First NL (1992) in vitro development of one-cell bovine embryos: influence of glucose, lactate, pyruvate, amino acids and vitamins. Theriogenology 37, 963-978

Trounson A, Pushett D, Macellan LJ, Lewis I, Gardner DK (1994) Current status of IVM/IVF and embryo culture in humans and farm animals. Theriogenology 41, 57-66

Vanderhyden BC, Armstrong DT (1989) Role of cumulus cells and serum on the in vitro maturation, fertilization and subsequent development of rat oocytes. Biol Reprod 40, 720-728

Vanderhyden BC, Armstrong DT (1990) Effects of gonadotropins and granulosa cell secretions on the maturation and fertilization of rat oocytes in vitro. Mol Reprod Dev 26(4), 337-346 
Van de Sandt JJM, Schroeder C, Eppig JJ (1990) Culture media for mouse oocyte maturation affect subsequent embryonic development. Mol Reprod Dev 25, 164-171

Yoshida M, Ishigaki K, Pursel VG (1992) Effect of maturation media on male pronucleus formation in pig oocytes matured in vitro. Mol Reprod Dev 31, 68-71

Yoshimura $Y$, Hosoi $Y$, Iritani A, Nakamura $Y$, Atlas SJ, Wallach EE (1989) Developmental potential of rabbit oocyte matured in vitro: the possible contribution of prolactin. Biol Reprod 41, 26-33

Younis Al, Brackett BG, Fayrer-Hosken RA (1989) Influences of serum and hormones on bovine oocyte maturation and fertilization in vitro. Gamete fies 23 , 189-201
Younis Al, Zuelke KA, Harper KM, Oliverira MAL, Brackett BG (1991) In vitro fertilization of goat oocytes. Biol Reprod 44, 1177-1182

Zhang $X$, Armstrong DT (1989) Effects of follicle-stimulating hormone and ovarian steroids during in vitro meiotic maturation on fertilization of rat oocytes. Gamete Res 23, 267-277

Zhang X, Rutledge J, Armstrong DT (1991) Studies on zona hardening in rat oocytes that are matured in vitro in a serum-free medium. Mol Reprod Dev 28(3), 292-296

Zuelke KA, Brackett BG (1990) Luteinizing hormoneenhanced in vitro maturation of bovine oocytes with and without protein supplementation. Biol Reprod $43,784-787$ 